\title{
Taxpayers' Compliance in the City of Jambi
}

\author{
Wiwik Tiswiyanti ${ }^{1 *}$, Kamadie Sumanda $^{2}$, Wirmie Eka Putra ${ }^{3}$
}

\author{
${ }^{12,3}$ Ecomomics and Business Faculty, Universitas Jambi \\ Jalan Raya Jambi-Muara Bulian Km 15, Muaro Jambi, Jambi, Indonesia \\ *Corresponding author Email: wiek-muis@unja.ac.id
}

\begin{abstract}
Taxpayer compliance is an act of obeying and being aware of taxation provisions. This study aims to analyze the factors that influence taxpayer compliance in the city of Jambi. The variables examined in the study were tax amnesty and taxpayer knowledge. Respondents in the survey were taxpayers, both individuals, and clients at the tax consulting office in Jambi. The study population was 465 , with purposive sampling, obtained 46 samples. The results show that tax amnesty and tax knowledge affect taxpayer compliance in the city of Jambi.
\end{abstract}

Keywords: tax amnesty, tax knowledge, taxpayer compliance.

\section{INTRODUCTION}

Every Indonesian citizen, according to the tax laws, is obliged to pay taxes to support development. Taxes cannot automatically collect from the public because tariffs are a burden due to binding regulations, so they are forced to pay them. That requires taxpayers to have awareness in fulfilling tax obligations to develop the nation and state [1].

In 2016 the government issued Law no. 11 regarding tax amnesty. Empirical evidence shows that tax amnesty has been running for the last twenty years in the United States, reaching forty countries. Tax amnesty is an offer to settle tax payable for an amount less than the current debt without incurring additional delays and other penalties [2], [3]. The goal [4] is to increase tax compliance and revenue, hoping that [5] the tax amnesty policy will increase revenue in the tax sector.

The basis for acting in making decisions to implement rights and obligations, taxpayers must have tax knowledge [6] which includes [7] General Provisions and Tax Procedures (KUP), the Indonesian tax system, and tax functions. If this concept implements appropriately and correctly, tax sanctions will avoid, and [8], [9] taxpayer compliance will also increase.

Compliance is related to knowledge and understanding. Obey means obeying rules, discipline, following orders
[10]. Compliance can be defined as [5], [11] a situation where taxpayers comply with all their tax obligations and rights. And taxpayers can be said to be compliant if they meet the criteria as stated in the Decree of the Minister of Finance No. 235 / KMK.03 / 2003 dated 3 June 2003 concerning Criteria for Taxpayers Who Can Determine as Compliant Taxpayers. The criteria for compliant taxpayers were also stated by [12], [13] in 4 (four) categories, namely 1). Taxpayers understand or try to understand all the provisions of tax laws, 2). Fill out the tax form completely and clearly, 3). Calculating the amount of tax owed correctly 4). Pay taxes owed on time.

The results of an empirical study on tax amnesty, stated among others by [5], show that there is a decrease in the level of compliance after the implementation of the tax amnesty program [14]-[17]. While [18], 1986 states that tax amnesty for any reason affects tax compliance both positively and negatively. Research on taxation knowledge conducted by [15] shows a positive and significant impact of tax knowledge on taxpayer compliance.

This study aims to determine the effect of tax amnesty and tax knowledge on taxpayer compliance, both simultaneously and partially. This study is different from previous studies because the researcher's sample is 
taxpayers who are clients of tax consulting offices, both individual and corporate taxpayers in Jambi.

\section{LITERATURE REVIEW}

Tax amnesty is a limited opportunity for certain taxpayers to carry out tax obligations in the past. That is similar to what was conveyed by [19] that Tax amnesty provides an opportunity for non-compliant taxpayers to become compliant and increase revenue. With the more obedient taxpayers to provide a more accurate list of assets, the tax sector's income will also increase [20].

Taxpayers' behavior to implement tax amnesty based on attribution theory is an external cause that affects taxpayer compliance in carrying out their obligations. This theory studies how a person interprets an event or becomes a cause for the behavior. This theory was first developed by [21]. He argued that there is a combination of internal and external forces that determine a person's behavior [16].

Previous research conducted by [2], [14], [16], [18] provides empirical evidence that there is a positive and significant effect of tax amnesty on taxpayer compliance. So that the research hypothesis

\section{H1: Tax Amnesty affects Taxpayer Compliance.}

Tax knowledge provides information that taxpayers can use in carrying out their tax obligations. With the understanding of taxation, taxpayers can calculate, deposit and report their taxes. And with knowledge and knowledge of tax provisions can increase taxpayer awareness and compliance. The level of expertise possessed by taxpayers will influence the decision to comply with their tax obligations [22].

Knowledge of tax regulations to carry out tax obligations based on attribution theory is an internal cause that affects the taxpayer's perception of being obedient [16]. Previous research has shown that knowledge has a positive and significant impact on taxpayer compliance by [2], [15], [17], [18], So the research hypothesis:

H2: Tax knowledge affects Taxpayer Compliance.

\section{RESEARCH METHOD}

The research method uses multiple linear regression analysis. The study population was 465 taxpayers, individuals, and entities with 9 (nine) Tax Consultant Offices in the Jambi City area. With a purposive sampling technique, obtain a sample of 45 respondents. Hypothesis testing uses classical assumptions, hypothesis testing (RSquare test, $\mathrm{F}$ test, and t-test). With the regression equation:

$$
\mathrm{Y}=\alpha+\beta 1 X 1+\beta 2 X 2+e
$$

Information:

$\mathrm{Y}=$ Taxpayer Compliance

$\alpha=$ Constant

$\mathrm{X} 1=$ Tax Amnesty

$\mathrm{X} 2=$ Tax Knowledge

$\beta 1, \beta 2,=$ Regression Coefficient

e $=$ Error Term

\section{DATA ANALYSIS METHOD}

\subsection{Multiple Linear Regression Analysis}

Multiple regression analysis performs to determine the effect of the independent variable on the dependent variable. And the results can see in the table :

Table 1. Multiple Linear Regression

\begin{tabular}{|c|c|c|c|c|c|}
\hline \multirow[t]{2}{*}{ Model } & \multicolumn{2}{|c|}{$\begin{array}{c}\text { Unstandardized } \\
\text { Coefficients }\end{array}$} & \multirow{2}{*}{$\begin{array}{c}\begin{array}{c}\text { Standardized } \\
\text { Coefficients }\end{array} \\
\text { Beta }\end{array}$} & \multirow[t]{2}{*}{$\mathbf{t}$} & \multirow[t]{2}{*}{ Sig. } \\
\hline & B & Std. Error & & & \\
\hline (Constant) & 2,730 & 3,443 & & ,793 &, 432 \\
\hline $\mathrm{X} 1$ & ,349 & ,134 & ,329 & 2,601 &, 013 \\
\hline $\mathrm{X} 2$ & ,348 &, 105 & ,436 & 3,319 &, 002 \\
\hline
\end{tabular}

Source: Output SPSS

The following is the equation for the regression results that form:

$$
Y=2,730+0,349 X_{1}+0,348 X_{2}+e
$$


The multiple linear regression equation above can interpret that:

a) The positive constant value is 2.730 . That means that if the tax amnesty and tax knowledge are assumed to be 0 (zero), then the value of taxpayer compliance will constantly be worth 2,730 .

b) The regression coefficient value for the favorable tax amnesty variable is 0.349 . A positive value shows that changes in taxpayer compliance are in line with changes in tax amnesty. That means that if the tax amnesty value increases, the taxpayer compliance value will also increase.

c) The regression coefficient value for the favorable tax knowledge variable is 0.348 . A positive value indicates that changes in taxpayer compliance are in line with changes in tax knowledge. That means that if the value of tax knowledge increases, it will increase the value of taxpayer compliance.

Table 2. Test F (Simultaneous Test)

\begin{tabular}{|c|c|c|c|c|c|}
\multicolumn{7}{c|}{ Model } & $\begin{array}{c}\text { Sum of } \\
\text { Squares }\end{array}$ & df & $\begin{array}{c}\text { Mean } \\
\text { Square }\end{array}$ & F & Sig. \\
\hline Regression & 94,661 & 2 & 47,331 & 14,185 &, $000^{\mathrm{b}}$ \\
\hline Residual & 140,139 & 42 & 3,337 & & \\
\hline Total & 234,800 & 44 & & & \\
\hline
\end{tabular}

a. Dependent Variable: $y$

b. Predictors: (Constant), x2, x1

Source: Output SPSS

The table shows that Fount's value is 14.185 with a significance level of $0.000<0.05(\alpha=5 \%)$. That means that tax amnesty, knowledge of taxation simultaneously affects taxpayer compliance.

Table 3. Test $\mathrm{t}$ (Partial Test)

\begin{tabular}{|c|c|c|c|c|c|}
\hline \multirow{2}{*}{ Model } & \multicolumn{2}{|c|}{$\begin{array}{c}\text { Unstandardized } \\
\text { Coefficients }\end{array}$} & $\begin{array}{c}\text { Standardized } \\
\text { Coefficients }\end{array}$ & \multirow{2}{*}{ T } & \multirow{2}{*}{ Sig. } \\
\cline { 2 - 4 } & B & $\begin{array}{c}\text { Std. } \\
\text { Error }\end{array}$ & Beta & & \\
\hline (Constant) & 2,730 & 3,443 & &, 793 &, 432 \\
\hline $\mathrm{x} 1$ &, 349 &, 134 &, 329 & 2,601 &, 013 \\
\hline x2 &, 348 &, 105 &, 436 & 3,319 &, 002 \\
\hline
\end{tabular}

Source: Output SPSS

The test results show that:

- Tax amnesty obtained a value of 2.601 with a significance level of $0.013 \quad(0.013<0.05)$, indicating that the hypothesis is acceptable, meaning that tax amnesty partially affects taxpayer compliance.

- Knowledge of taxation obtains a value of 3,319 with a significance level of $0.002(0.002<0.05)$. That shows that the hypothesis is accepted, meaning that taxation knowledge partially affects taxpayer compliance

\section{RESULT AND DISCUSSION}

The results of the distributed questionnaires show a $100 \%$ return rate of the questionnaire. The returns results can describe that most respondents' age is between $46-55$ years or $38 \%$ of the total respondents. Meanwhile, the lowest age was 56 and over, as much as $2 \%$. Judging from the education they have, the respondents, on average, have a bachelor's and master's degree education at $49 \%$ respectively, while only $2 \%$ have diploma education. Based on the income obtained, as many as $36 \%$ are respondents who earn up to Rp. 50,000,000, while respondents who have an income above Rp. $500,000,000$ only $2 \%$ of the total respondents.

All respondents' answers show that most respondents agree with the question about tax amnesty, which means that respondents respond well to tax amnesty and participate in the tax amnesty 
program. Respondents are aware that Tax amnesty can improve taxpayer compliance in carrying out their tax obligations, encourage honesty in voluntary reporting of taxpayers' wealth data. Tax amnesty is a transitional tool towards a new tax system that agrees that tax amnesty can increase revenue for the state.

The respondents' answers indicate that all respondents have sufficient knowledge of taxation and are obedient to their obligations as taxpayers, where respondents know the applicable tax obligations, respondents know the regulations regarding the tax reporting deadline that set. Almost all respondents know about sanctions in the taxation field. Respondents see the tax administration procedure. Nearly all respondents see the difference between VAT and PPh, and respondents know the tax system.

The respondent's answer is obedience to being a taxpayer by trying to comply with tax laws, filling in tax forms correctly, and reporting on time, meaning that the respondent knows and complies and tries to understand the Taxation Law and understands how to fill out tax forms correctly. Pay taxes according to the actual nominal, pay taxes on time, report taxes on time.

\section{DISCUSSION}

\subsection{The Effect of Tax Amnesty on Taxpayer Compliance.}

The partial test results show that tax amnesty affects taxpayer compliance. The results of this study support the tax amnesty program that the government has established. Implementing this program will encourage taxpayers to be more obedient in fulfilling their tax obligations to increase the number of registered taxpayers who have not net so far. That will indirectly increase state revenue from the tax sector and increase the tax ratio.

This research supports the theory expressed [23] that the tax amnesty policy will increase tax compliance and revenue. And in line with previous research conducted by [14]-[16], [18], which shows that tax amnesty has a significant positive effect on taxpayer compliance. But it is not in line with previous research conducted by [5], indicating that the level of compliance decreased after implemented the tax amnesty program.

\subsection{The Influence of Tax Knowledge on Taxpayer Compliance}

The partial test results show that tax knowledge affects taxpayer compliance. The self-assessment system adopted in Indonesian taxation requires taxpayers to know about taxation because this system gives taxpayers complete confidence to calculate, deposit, and self-report the amount of tax owed to the State treasury. Therefore, taxpayers expect to understand and understand tax laws and regulations. So that with the knowledge of taxation, the taxpayer can carry out their obligations.

This research is in line with the study of [2], [15], [17], which proves that tax knowledge has a positive and significant effect on taxpayer compliance.

\section{CONCLUSION}

Based on the results of the analysis on the effect of tax amnesty, tax knowledge, and tax services for taxpayers, it can serve as follows:

1. Tax Amnesty affects Taxpayer Compliance. That means that taxpayers support the tax amnesty program that the government has established. The Amnesty tax program's application encourages taxpayers to be more compliant with fulfilling their tax obligations, both for registered taxpayers and those who have not net.

2. Knowledge of Taxation affects Taxpayer Compliance. Having experience of taxes is a must, related to the government's self-assessment system, in which taxpayers entirely entrust with calculating, depositing, and reporting the amount of tax owed by themselves. With an understanding of taxation, taxpayers will be more obedient and avoid tax sanctions.

\section{AUTHORS' CONTRIBUTIONS}

Wiwik Tiswiyanti, Kamadie Sumanda, Wirmie Eka Putra

WIK; Assignments to design research methods, analyze data, and co-write research. KAM; Tasked with collecting research data, processing data, and responsible for editing the research language. WIR; Tasked with sending various references related to research and together in editing the research language.

\section{REFERENCES}

[1] W. E. Putra, Yuliusman, and R. F. Wisra. 2020. "THE RELATIONS AMONG FIRM CHARACTERISTIC, INTENSITY, CAPITAL OWNERSHIP, AND TAX AVOIDANCE: SOME EVIDENCE FROM INDONESIA," 
Humanit. Soc. Sci. Rev., Vol. 8, No. 1, Pp. 315-322.

[2] M. Nar, 2015. "The effects of behavioral economics on tax amnesty," Int. J. Econ. Finance. Issues, vol. 5, no. 2.

[3] N. Sayidah and A. Assagaf. 2019. "Tax amnesty from the perspective of a tax official," Cogent Bus. Manag., vol. 6, no. 1, p. 1659909, 2019.

[4] E. W. Said. 1993. "Tax policy in action: 2016 tax amnesty experience of the Republic of Indonesia," Laws, vol. 6, no. 4, p. 16, 2017.

[5] J. Alm and W. Beck. 2009. "Tax amnesties and compliance in the long run: A time series analysis," Natl. Tax J., pp. 53-60, 1993.

[6] V. Carolina. 2009. Pengetahuan Pajak. Jakarta, Indonesia: Salemba Empat, 2009.

[7] W. E. Putra, A. Mirdah, and P. Y. Siregar. 2020. "Determinan Faktor- Faktor Yang Mempengaruhi Minat Wajib Pajak Dalam Penggunaan E-Filing," Sist. Informasi, Keuangan, Audit. Dan Perpajak., vol. 4, no. 2, pp. 173-187.

[8] G. Richardson, G. Taylor, and R. Lanis. 2013. "The impact of board of director oversight characteristics on corporate tax aggressiveness: An empirical analysis," $J$. Account. Public Policy, vol. 32, no. 3, pp. 6888.

[9] E. Kirchler. 2007. The economic psychology of tax behavior. Cambridge University Press, 2007.

[10] D. Anouar and Z. Houria. 2017. "The Determinants of Tax Avoidance within Corporate Groups : Evidence from Moroccan Groups," Int. J. Econ. Finance. Manag. Sci., vol. 5, no. 1, pp. 57-65.

[11] W. E. Putra, I. L. Kusuma, and M. W. Dewi. 2019. "Analisis Faktor-Faktor yang Mempengaruhi Kepatuhan Wajib Pajak (Studi Kasus pada Wajib Pajak Orang Pribadi dan Badan di Wilayah Kota Jambi)," J. Akunt. dan Pajak, vol. 20, no. 01, pp. 43-54.

[12] N. E. Ruki, W. E. Putra, and F. Mansur. 2018. "Jurnal riset akuntansi \& keuangan," J. Ris. Akunt. DAN Keuang., vol. 6, no. 3, pp. 405-
418.

[13] M. Zain. 2017. Perpajakan. Jakarta, Indonesia: Salemba Empat.

[14] N. Ngadiman and D. Huslin. 2015. "Pengaruh Sunset Policy, Tax Amnesty, dan Sanksi Pajak Terhadap Kepatuhan Wajib Pajak (Studi Empiris di Kantor Pelayanan Pajak Pratama Jakarta Kembangan)," J. Akunt., vol. 19, no. 2, pp. 225-241.

[15] S. Suyanto, P. P. L. A. Intansari, and S. Endahjati. 2016. "Tax amnesty," J. Akunt., vol. 4, no. 2, pp. 9-22.

[16] N. Alfiyah and S. W. Latifah. 2017. "Pengaruh Pelaksanaan Kebijakan Sunset Policy, Tax Amnesty, Dan Sanksi Pajak Terhadap Kepatuhan Wajib Pajak Orang Pribadi," J. Reviu Akunt. Dan Keuang., vol. 7, no. 2, pp. 1081-1090.

[17] C. O. Olaoye, S. A. Ogunleye, and F. T. Solanke. 2018. "Tax audit and tax productivity in Lagos state, Nigeria," Asian J. Account. Res., 2018.

[18] A. H. Lerman. 1986. "Tax amnesty: The federal perspective," Natl. Tax J., vol. 39, no. 3, pp. 325-332.

[19] S. Devano and S. K. Rahayu. 2006. Perpajakan: Konsep Teori dan Isu. Jakarta, Indonesia: Kencana, 2006.

[20] R. Rudiantoro and S. V. Siregar. 2012. "Kualitas Laporan Keuangan UMKM Serta Prospek Implementasi SAK ETAP," J. Akunt. dan Keuang. Indones., vol. 9, no. 1, pp. 1-21, 2012.

[21] H. Fritz. 1958. "The psychology of interpersonal relations." New York: John Wiley and Sons.

[22] Y. A. Siregar, S. Saryadi, and S. Listyorini, 2012. "Pengaruh pelayanan fiskus dan pengetahuan perpajakan terhadap kepatuhan wajib pajak (studi empiris terhadap wajib pajak di semarang tengah)," J. Ilmu Adm. Bisnis, vol. 1, no. 2, pp. 295-304.

[23] Mardiasmo. 2018. Perpajakan (Edisi Terbaru 2018). Yogyakarta Indonesia.: Andi Offest, 2018. 